\title{
A Study of Using E-Writing Instructional Design Program to Develop English Writing Ability of Thai EFL Learners
}

\author{
Pongpatchara Kawinkoonlasate ${ }^{1}$ \\ ${ }^{1}$ English Department Faculty of Liberal Arts, Huachiew Chalermprakiet University, Samut Prakarn, Thailand \\ Correspondence: Pongpatchara Kawinkoonlasate, English Department Faculty of Liberal Arts, Huachiew \\ Chalermprakiet University, Samut Prakarn, Thailand.
}

Received: April 24, 2021

doi: $10.5539 /$ elt.v14n6p43
Accepted: May 17, 2021

Online Published: May 17, 2021

\begin{abstract}
Learning with technology has become essential in today's education not only in Thailand but also all around the world. Technology has been an important tool for improving language learners' reading writing, speaking, and listening for quite some time. Writing, however, has been one of the most supported skills thanks to technology. Learning how to write paragraphs or essays is an essential skill for learners. The purposes of this quasi-experimental study were:

1) to examine the effectiveness of the e-Writing instructional design program in developing the writing skills of EFL learners, 2) to explore learners' satisfaction and motivation toward the e-Writing instructional design program, and 3) to study learners' autonomy after completing the e-Writing instructional design program. This study employed the purposive sampling method to select 33 second-year learners. Lesson plans, e-writing programs, learner perception questionnaires, interviews, as well as a pre and post-test were the tools used to gather relevant data. A t-test with standard and average deviation was used to investigate the quantitative data.

Interview data were analyzed using content analysis. The quantitative findings revealed that the writing achievement level of the learners before and after receiving the treatment was significantly different at 0.001 . The learners' post-test scores of 33 learners increased over the pre-test scores. From the questionnaire results, the satisfaction level of undergraduate learners toward the instruction of this course had average scores of 4.34 which was an excellent level.

Furthermore, interviews revealed that learners are satisfied with the e-Writing instructional design program because this could improve learners' writing skills and promote more learner autonomy. Recommendations are made and presented in terms of future practical application and future research needs to be done to analyze results and the effects of future outcomes.
\end{abstract}

Keywords: e-writing instructional design program, English writing ability, autonomous learning, motivation

\section{Introduction}

In the 21 st century, modern technology is an increasingly important aspect of human life and has dramatically changed the lifestyle of educational organizations and staff including instructors and learners. People around the world use technology all the time. They can access easily through social networks because technology is a tool that could improve many other aspects of life such as business, economy, education, health, and so forth. In terms of education, instructors, learners, and parents all benefit from using technology resources, personalized learning materials, and opportunities for advanced learning. The learners are able to use the internet to share new knowledge, communicate, and practice their studies. Technology in education now offers plenty of chances to transform global education at all age levels, and it provides opportunities for worldwide learning resources. Consequently, in terms of education, learning English language and applying technological devices are crucial for all learners which is a foundation requirement for the learning atmosphere and environment. Technology in education has been implemented in the educational system because engaging with technology in the classroom has not only assisted the learners to learn effectively, but they are also getting multi-tasking skills.

Digital communication, freedom in scheduling, more freedom of choice, and relevant materials can all be provided by technology in the classroom (Haris, Yunus, \& Badusah, 2017). Technology is concerning very frequently, helps learners to learn concepts easily, and increases the importance of technology in education. In regards to learning 
English as a foreign language or (EFL), and English as a second language, or (ESL), technology can give learners and instructors more access to tools that can promote learning outcomes. The use of technology namely social networking sites facilitates teaching and learning. Technological devices and innovation might lead educational staff to forget the basic pedagogical principles which underlie autonomous language teaching (AbuSeileek \& Abualsha'r, 2014; Kranthi, 2017). Even today, language is considered as one of the most essential elements of education and literacy both in receptive and productive skills. In the productive skills of language, writing skills are one of the most important skills, often linked to other skills, and the preferred outcome of learners. All the educational institutions place great importance on writing skills. The learner's motivation is very important when practicing writing in English. Interesting teaching methods and engaging strategies need to be employed for positive results. Using the technologies in education might be useful for learners to create a good learning environment. To understand the learners' strengths and weaknesses, educators need to employ a variety of writing activities (Stine, 2010; Alanazi, 2013).

Even if a learner is not a strong writer, proper activities and techniques can help them become a better writer. Since starting to teach English essay writing courses, this has seen that learners might not be familiar with essay writing and find it difficult in their writing. It is different from what they have written in their previous course. The learners are required to follow the rules of essay writing in English. Moreover, word choice, grammatical structures, and vocabulary choice might be difficult for learners when practicing writing. Organization of essay and giving supporting details in body essay were considered because these allowed the learners incapable of expressing ideas. Another thing found that the learners' motivation in attending writing practicing and learning is still low. This could be seen from the learners' writing task and some learners inform the instructor personally. Considering these problems mentioned above, the problem results because of inadequate methodology. Virtual classes, traditional in-person classes, and hybrid classes, using both, can be used to effectively promote organizing an essay, and motivation (Albalawi, 2015). The attempt of modifying an innovative learning method by the instructors in writing learning could motivate the learners and save time. According to the study of Gregoriades, Pampaka, and Michail (2009) the instructors should select an effective teaching delivery method to teach the learner as understanding learners' learning style and using a suitable teaching delivery method leads to meaningful learning. For educators to be successful, they need to carefully choose their teaching methodology (Ahmadi, 2017).

Based on research done by (Rojas, 2011; Peregoy \& Boyle, 2012; Genç lter, 2015; Parvin \& Salam, 2015; Pourhosein Gilakjani, 2017), instructors need to find interesting and engaging ways for learners to use their language skills through technological tools and activities. Hence, the path to improving learners' English writing skills might provide suitable teaching delivery methods and modern teaching media to stimulate their desire for interacting in the target language and to create various opportunities for them to practice. Through the use of e-Writing, this study aims to categorize useful teaching methods for Thai EFL learners who are struggling to write in English. Consequently, the goals of this study are set:

1) To examine the effectiveness of e-Writing instructional design program in developing writing skills of EFL learners.

2) To explore learners' satisfaction and motivation toward e-Writing instructional design program.

3) To study learners' autonomy after receiving e-Writing instructional design program.

This study aims to discuss more interesting ways learners can practice writing using technology.

The following research questions are put forth to understand the effectiveness of an e-Writing course.

1) Are there any differences in learners' e-Writing instructional design programs before and after their study?

2) What are the effects of e-Writing instructional design programs on learner satisfaction and motivation?

3) How does the e-Writing instructional design program promote autonomous learning? 
Conceptual Framework

Independent Variable
Dependent Variable
1. Learners' English essay writing ability

2. Learners' satisfaction and motivation toward the course

3. Autonomous learners

Figure 1. Conceptual framework of this study

According to this conceptual framework, the independent variable in this study is the teaching delivery method consisting of an e-Writing instructional design program. The dependent variable in this study depends on learners' English essay writing ability, learners' satisfaction and motivation toward the course, and autonomous learners.

\section{Literature Review}

\subsection{The Importance of Writing Skills and Instruction}

As global communication expands all areas of the world, most learners will need to use their writing skills to formally communicate with others in their professional lives. Effective writing skills are necessary for learners. Literacy is often based on a learner's ability to write in English. Walsh (2010) pointed out that most learners will use their writing skills in higher education or after they graduate in their work environment. Writing offers learners the path to learn all the rules of their language and how they can better organize their ideas more coherently using the language. Most scholars believe that writing is the quite important skill for a learner to be competent in (Chappell, 2011; Sawalmeh, 2013). Moreover, a learner's writing ability is a culmination of all their language skills. Being able to explain complex thoughts is crucial for a learner to be able to do while writing. For a learner to create a satisfactory text they need to be able to gather important information and create a link to the overall topic of the essay. Ridha (2012) suggested that writing can expand a learner's grammar, sentence structure, and vocabulary. Each paragraph a learner creates needs to be carefully crafted using all of their language knowledge.

In an academic environment, writing is a crucial tool for finding new ideas, understanding complex information and sharing important data (Graham, Gillespie, \& McKeown, 2013). Written text is permanent and allows others to analyze and expand upon it in a learning environment (Graham, Gillespie, \& McKeown, 2013). In a classroom, instructors might have learners write a story to explain an idea. To promote the learners' writing skills, the teaching methodology in writing instruction will be an important strategy to improve them because writing involves a complex process including technology, such as the internet, in a language lesson can be used to increase the learner's motivation towards writing. The internet can be used for all ages to stimulate literacy (Malloy and Gambrell, 2006). Scott and Mouza (2007) point out that the writing skill is very important whether the learner is young or old. The writing skill can influence a learner's autonomy, self-control in social situations, personal skills, decision making, and social abilities.

\subsection{Stages and Activities of the Writing Process}

Teaching writing is a long process. It can be a major indicator of a learner's progress. Approaches that use process writing have multiple steps. Fortunately, there is already a large body of research on this topic. According to Albesher (2012), learners need to follow four main steps to become proficient writers.

1) Pre-writing (Identifying the objective of a text and organizing a plan to complete it)

2) Composing

3) Revising (understanding what the main objective of the text is and alerting it for the intended audience)

4) Editing (reviewing grammar and spelling and correcting it)

Whereas Harmer (2011) classified the process approach to writing into planning, drafting, editing, and the final version. 


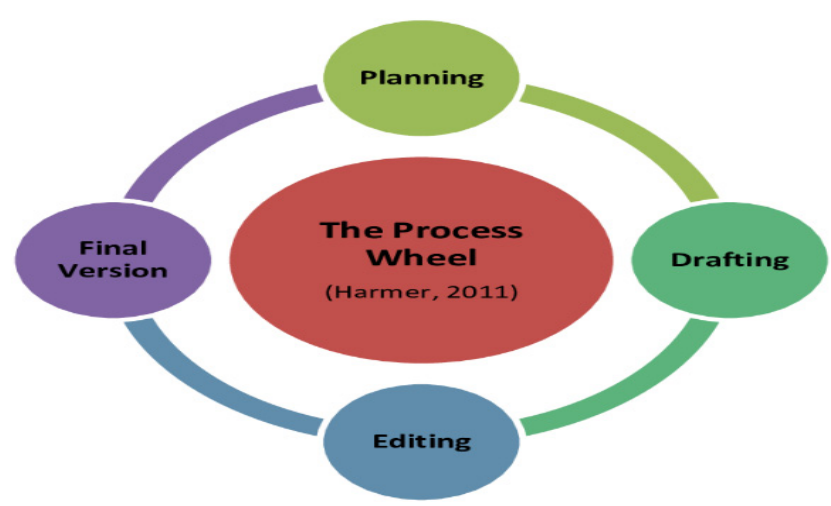

Figure 2. The Writing Process Wheel (Harmer, 2011)

Harmer (2011) mentioned that the stages of process writing involved

1) Prewriting: finding the ideas, collecting information, and organizing the thoughts

2) Drafting: developing the meaning using ideas in pre-writing

3) Peer review: seeking and responding to their peer

4) Reflection: the writer can understand what parts of the text are incomplete or lacking

5) Proofreading and editing: the writer can analyze the whole text and make changes to grammar, vocabulary, or text which does not support the main purpose of the text. Essay writing involves four main steps: prewriting, creating a draft, revision, and editing the final draft.

In this study, following these four steps is called recursive writing. While the learner is doing any of these steps they may need to go back and rewrite previous steps when needed as in figure 3 .

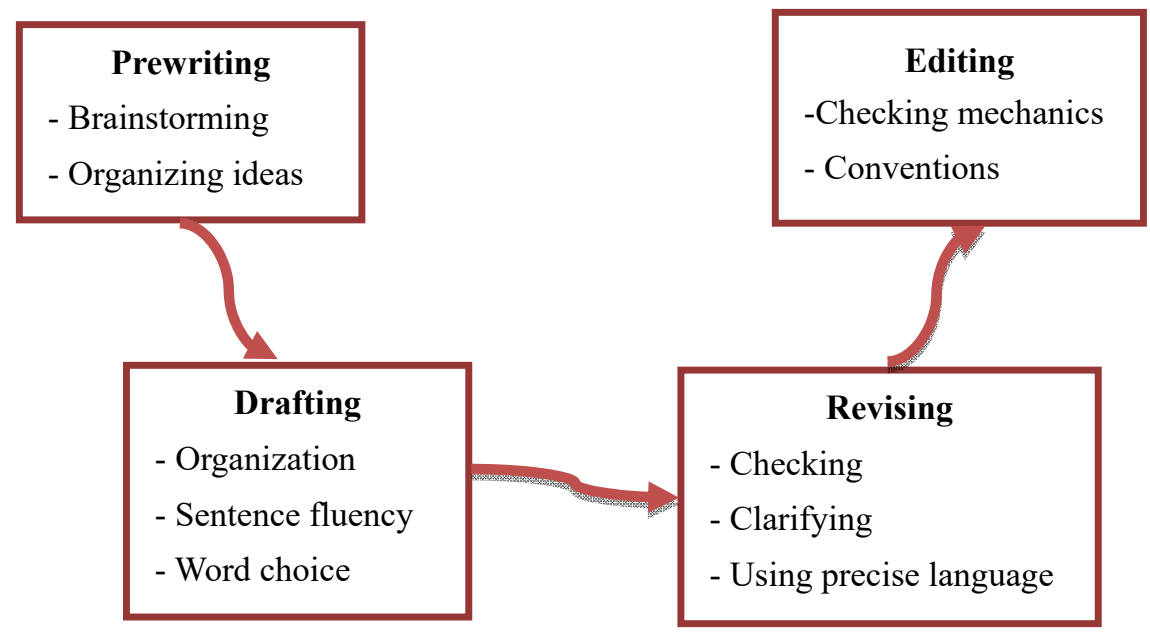

Figure 3. Four steps in essay writing (Albesher, 2012)

\subsection{Learner Writing Methods}

How learners compose their writing can be tied to their personal, ethnic, economic, or social background. This could be called the technique or style of a writer. The learners writing style is how they put together their text. It aids them in writing about feelings, information, or pictures they are trying to convey. The way a learner deciphers a text and conceptualizes it can also be affected by their style (Bouchrika, 2020). Potter (2019) explained that learners write in 4 common ways. Below I would like to briefly discuss these ways.

1) Expository writing. This style of writing is used to create text with the intent to explain or expose information to the readers. Textbooks, instruction booklets, and newspaper articles are usually created with expository writing. 
2) Persuasive writing. When a writer would like to try to convince the reader to see the world as the writer does, they might employ a persuasive writing style. The persuasive writing style is used in texts which aim to persuade the audience into understanding a topic in a specific way or encourage the reader to take action against another idea.

3) Narrative writing. To explain an idea some writers construct text similar to the way a story is constructed. The text might have a noticeable beginning climax and ending. This type of writing style is called narrative writing.

4) Descriptive writing. To give the reader a detailed picture writer can create a text descriptively. Writers can describe places, people, or periods based on their senses of the world.

Strong writing skills are useful to all learners regardless of what occupation or subject they are involved in. Being able to use a variety of writing skills can make a learner more confident in the text they are creating. Explanatory essays, problem-solution essays, comparison and contrast essays, and persuasive essays are the 4 main types of essays Thai educators have been tasked to teach under the Thai Qualifications Framework for Higher Education (TQF3 of essay course). Learners are required to produce these 4 types of essays based on their interests and experiences. They must follow a writing process that includes prewriting, drafting, revising, and then editing.

\subsection{Error Analysis in English Writing}

The process of investigating errors made by $\mathrm{L} 2$ learners is called error analysis (EA). Writing mistakes can be used to identify L2 learners writing performance (Sarfraz, 2011; Salima, 2012). A great way to help promote learners' writing skills is to encourage them to understand their errors. Writing, in English, can be very challenging for EFL learners. Over the past decade, studies have been conducted on EFL university learners' essay writing and the errors that occurred (Maniam, 2010; Al-haysoni, 2012; Zawahreh, 2012; Kathryn Sorg, 2014). To do a good job, the instructor should clearly understand the different types of errors that most learners usually make to explain them to the learners and to anticipate problems. During the process of language learning, error analysis is a valuable tool. It can aid learners in understanding a language more fully. Error analysis is also effective at clarifying a learner's strengths and weaknesses. Error analysis is a great tool that instructors should try to encourage learners to use. The information gained can promote learner autonomy and give the learners clear goals to meet in their educational journey.

\subsection{E-Writing Instructional Design Program on English Language Learning}

In educational contexts, technology can be used to promote learning in and out of the classroom. Despite a learner's age, the writing skill is critical (Scott \& Mouza, 2007). Studies have shown that learners feel more positive expressing their ideas and feelings in text form rather than verbally (Cobanoglu \& Berezina, 2011; Omar \& Miah, 2012; Purcell, Buchanan \& Friedrich, 2013). Computer programs and websites are great places for learners to share their personal opinions and feelings. Encouraging learners to use these programs can lead to more meaningful texts. Furthermore, technology is a tool that can be used to stimulate learners' writing skills in an engaging way. Technology should be used by instructors to meet the curriculum and class objectives (David, Keaton, Morris, Murphy, \& Stapley, 2008). The traditional way text has been created has changed with technology. The definition of e-Writing in this study refers to the act of using electronic mediums to create and share texts. Google sites were used in this study to allow texts to be shared quickly and without cost. The learners in this study had previously used Google Docs and were familiar with how to use it properly. Technology has allowed writing to be taught in different ways. Technology can motivate and encourage some learners to write more. Google Docs is a great tool that can provide privacy for authors who might be worried about their peers criticizing their work (Cavender, 2012).

\subsubsection{The design of E-Writing Instruction Design Program}

In terms of using the e-Writing instructional program, this tool has also been used in developing writing skills with which learners could access the program and follow the user manual guideline. The e-Writing instructional program can help the learners develop higher levels of thinking skills, and it provides instructors new ways to interact with their learner's work. E-Writing also has the advantage of letting learners share ideas with their peers easily from anywhere they can access the internet (Peterson-Karlan, Hourcade, \& Parette, 2008). The study of David, Keaton, Morris, Murphy, and Stapley (2008) and Peregoy \& Boyle (2012) insisted that technology is a powerful tool to motivate learners and enable them to reflect on their learning achievement. When technological media is applied to a language lesson the learners reading and writing skills can increase rapidly through easy access. 
Learning that is facilitated by electronic technologies can be either fully online, mixed mode or web-assisted; however, regardless of the delivery method, the use of learning technologies can transform the concept of teaching and learning by redefining the role of the instructor and transforming the meaning and content of the learning procedure. E-Writing using Google Site to create the learner's tasks in this study is easy to access, organize and search. It also helps the learners to become involved in the assessment process. It can also promote the exchange of ideas and provide feedback. Learners can get feedback regularly and quickly because of the development of media channels. The design of e-writing instructional design program would be presented as the figure below.

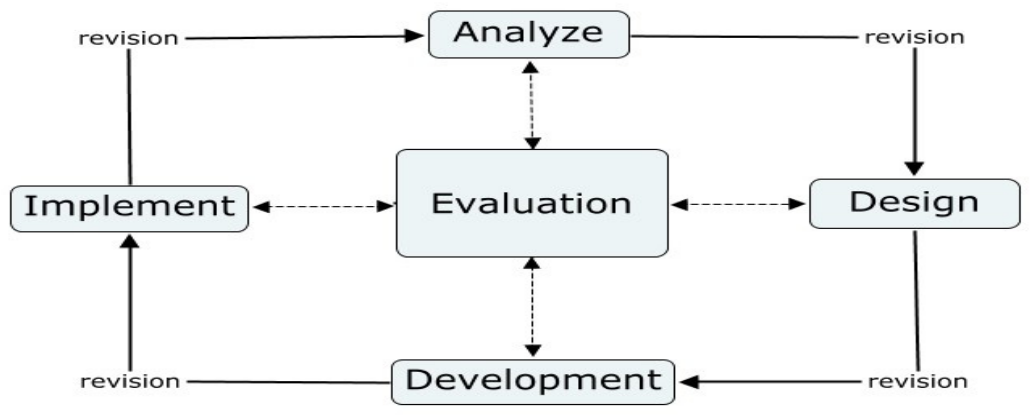

Figure 4. ADDIE model Adapted from (Allen, 2017)

ADDIE is a teaching approach that is commonly referenced. The acronym stands for:

1) Analysis: Educators need to be aware of their learner's needs. Educators should ask themselves if course objectives are attainable by their learners.

2) Design: When course objectives are set the educator needs to create a plan of action for getting the learners to the set goals.

3) Development: Instructors need to find relevant media and activities, which support the lesson plan, to motivate the learners to achieve the course objectives.

4) Implementation: The instructor needs to carry out the lesson plan. It is important that while the instructor is teaching the lessons, they are aware of the course objectives so as not to get sidetracked.

5) Evaluation: When the lessons are complete the instructor must evaluate their learners with quizzes, tests, or assignments. Based on the results of the evaluation the instructor should make further considerations about their lesson plans and course objectives.

ADDIE has been accepted by multiple researchers and has been called an effective and easy approach to integrate into a computer-based lesson plan (Davis, 2013; Lin, 2015; Branch, 2018). In this study, ADDIE has been applied to an e-Writing instructional program with the aim is to improve EFL learners' essay writing skills.

\subsection{Motivation and Autonomous Learning for English Writing}

Motivation and autonomous learning are crucial skills for language learners to have. These factors have been studied by educational psychologists for many years. Motivation is the heart of achievement. When a learner has high motivation, they will learn and master language much quicker than a learner with low motivation (Prakash, 2007). In addition, learning attitudes are important predictors of achievement. Autonomous learners are typically more motivated to learn. Taking part in activities and doing extra work outside of class can improve learners' skill levels faster than those who are less motivated. The atmosphere, an instructor creates in the classroom can encourage or discourage learner autonomy. Participation is also usually higher in highly motivated learners. Emily (2011) pointed out that motivation will develop learners' encouragement for their study, allowing them to study by themselves, and become autonomous learners. If learners are not engaging in the activities, an instructor is putting forth then the learners will improve slowly. Therefore, if learners feel motivated and are participating in the instructor's L2 writing lessons, a positive effect can occur in the learners writing skills. Incorporating positive feedback through written comments or verbal praise can promote learner motivation.

\subsubsection{Autonomous Learning in E-Writing Instructional Design Program}

Learning attitudes is important predictors of achievement. Learner autonomy is defined as a learner's ability to practice and learn on their own. Learner autonomy is a skill that most high-achieving learners have. Autonomous learning can greatly improve a learner's achievement scores (Dafei, 2007; Vurdien, 2013). Being aware of their 
thinking processes, or metacognition is required for learners to be successful autonomous learners (Little, 2007). For successful language learning, learners need to try to become less reliant on the instructor's lessons and more reliant on their self-guided learning. Instructors need to encourage autonomous learning if they want to see their language learners truly succeed. Technology can be a tool that promotes autonomous learning. Instructors should try to find interesting ways to incorporate technology into their lessons to promote learner autonomy and efficient learning outcomes (Razali \& Khatimah, 2013; Smith \& Craig, 2013; Merzifonluoglu \& Gonulal, 2018). Using technological devices might be a good pathway for the learners' learning processes.

\subsection{Advantages and Disadvantages of Applying Technology in Language Classrooms}

Applying technology into the language classroom is essential. Technology in the classroom has been proven to be no less effective than not using technology (Shadiev \& Yang, 2020). Some benefits of using technology in the classroom are promoting better input by the learners, creating authentic language situations, and making it easier for the instructor to give learners feedback. In addition, Cutter (2015) claimed that technological mediums and devices increase learners' motivation and complement their knowledge. There are technological tools available for practicing reading, writing, listening, and speaking in English. Many educators and researchers stated that the implementation of technology in language classrooms enhances learners' learning process, atmosphere, motivation, autonomous learning, and learning development (Basheer, 2013; Mollaei, 2013; Stanley, 2013; Marek, 2014; Oxkert, 2018). Therefore, applying technological education could have a positive effect on learners' motivation for both reading and writing skills. Fox's study (2014) insisted on this result by suggesting that technological tools have effects positively on learners. Learner interest can be printed with technology in the classroom.

Technology can make uninteresting topics more interesting for learners through fun activities and assignments. Forums and virtual learning environments can increase learner collaboration skills. Being able to share text digitally with peers can stimulate the learner's autonomy as well. Knowledge retention, through more participation, can be stimulated with technology in the classroom also. Learners' different needs can also be met with technology in the classroom. With technology, learners can learn at their own paces. They can skip ahead if the lesson is too easy or review previous lessons if it is too difficult. Finally, technology improves instruction. With a wide selection of different apps and software, technology can support the traditional teaching method and promote higher achievement. Instructors can employ existing technology at their institution with their lessons. Instructors and learners will be able to take on new roles in their learning environment.

Technology is not perfect however and studies have been done to shed light on some of the limitations. A study by Mohamed (2014) and Pourhosein, Banou \& Zabihniaemran, (2015) disputed that there is a connection between instructors' attitude toward technology in education and their experience. Some of them would decline to integrate technology in their instruction because they might have lots of teaching experience. Moreover, they might lack the knowledge to use technology and need to be trained which is more difficult. In some cases, the learners might have more experience and knowledge with technology. This situation could be embarrassing for the instructors and might cause them to avoid its use in their lesson planning.

\section{Research Methodology}

\subsection{Research Design}

This study aims to examine the effectiveness of the e-Writing instructional design program in developing writing essay skills of EFL learners, explore learners' satisfaction and motivation, and study learners' autonomy. The researcher designed a model for the e-Writing instructional design program. The researcher divided this study into two sections. The first section of the e-Writing instructional design program is extra content concerning essay writing strategies and essay structure of each essay type namely explanatory essay, a problem-solution essay, comparison and contrast essay, and persuasive essay. The second section is four kinds of essay writing with assignments. The research instruments in this study consisted of lesson plans, a model for an e-Writing instructional design program; chapters on writing strategies, and four kinds of writing paragraph topics with questionnaires related to the learner's perception, assignments, interviews, and pre and post-tests. The participants in this study were the learners who enrolled in the English Essay course. The 33 participants (one group) were chosen using the purposive sampling method. There were a limited number of learners enrolled in this course.

\subsection{Data Collection}

This research took place during the second semester of 2020. It was conducted for 15 weeks with a total of 15 sessions. The scores from this study do not affect the learners' grade average. After permission was granted, the learners produced the pretest, and the instructor-researcher explained the instructional technique which would be 
used during the class. The participants have instructed the lesson on essay writing and produce each assignment via an e-Writing instructional design program. There are four essay assignments. The instructor-researcher encouraged them to start writing their first draft while circulating the classroom to check on different learners, answer their inquiries, and provide feedback regarding what they have written. The learners were asked to finish the drafts at home before bringing them to the class in the next session. Then the instructor-researcher checked the class status and answered any inquiries learners might have before encouraging them to exchange their essays with their peers, read their classmates' essays, and provide feedback. After that, learners were encouraged to edit their essays based on the feedback. Learners finished editing and polishing their essays, and handed them to the instructor-researcher for final grading. Finally, the learners produced the post-test. A perception questionnaire was launched. Each participant was interviewed for a more in-depth understanding of their perception.

\subsection{Data Analysis}

The data in this research was gathered with quantitative and qualitative tools. The following steps were used to understand the data collected.

1) Pre and post-test scores were analyzed using the t-test method. To determine a significant difference between the pre and post-test scores a data analysis process involving the mean and standard deviation was used.

2) The mean and standard deviation were used to evaluate the data collected from the questionnaires.

3) Interview questions, the data were read, reread, and then coded. To categorize relevant data coding was used.

\section{Results}

Two sections of this study have been dedicated to the results of this study. The first section is focused on the results found from the quantitative data. The second section will cover results discovered from the qualitative data.

\subsection{The Following Section will Discuss the Quantitative Data}

The results of the essay writing test before and after receiving the study are presented as the following.

4.1.1 The Following Table Shows the Results of a Paired Sample T-Test Which Tested the Pre and Post-Test Scores

Table 1. Comparison of the pretest and posttest scores $(n=33)$

\begin{tabular}{llllll}
\hline Test & $\boldsymbol{n}$ & $\overline{\boldsymbol{X}}$ & $\boldsymbol{S D}$ & $\boldsymbol{t}$ & $\boldsymbol{S} \boldsymbol{\text { Sig }}$ \\
\hline Pretest & 33 & 14.55 & 2.796 & -14.852 & $.000^{* *}$ \\
Posttest & 33 & 21.73 & 1.376 & & \\
\hline
\end{tabular}

Table 1, The paired sample statistics from the t-test were used to analyze the differences between the pre and post-test scores. The results of the pre and post-tests were scored based on the following point system:

1) The writer's ideas are supported by data and experiences. (10 points)

2) Essay structure (10 Points)

3) Central point and description of ideas (5 Points)

4) Design (5 Points)

Therefore, the results show that the Pre-test and Post-test scores (30 points) of had statistical significance at the 0.001 level. The pre-test mean scores were lower than the post-test mean scores.

\subsubsection{In the Following Table the Results from the T-Test Show the Pre and Post-Test Scores}

Table 2. Level scores of pretest scores and posttest scores $(n=33)$

\begin{tabular}{lllllll}
\hline \multirow{2}{*}{ Evaluation Lists } & \multicolumn{5}{c}{ Level scores } \\
\cline { 2 - 6 } & Excellent & Good & Fair & Poor & Very poor & Missing \\
\hline Pre-test & - & $3(9.1)$ & $23(69.7)$ & $7(21.2)$ & - & - \\
Post-test & $2(6.1)$ & $31(93.9)$ & - & - & - & - \\
\hline
\end{tabular}

The pre and post-test scores from the Essay Writing course from 30 points found that the 23 learner's pre-test scores were at the fair level which had $69.7 \%$, followed by 7 learners pre-test scores were at the poor level which had $21.2 \%$, and 3 learners' pre-test scores were at a good level which had $9.1 \%$. Whereas, 31 learners' post-test 
scores were at the good level which had 93.9\%, followed by 2 learners' post-test scores were excellent which had $6.1 \%$.

4.1.3 In the Next Table the Results from the Paired Sample T-Test, with Regards to the Pre and Post-Tests, are Given

Table 3. The different levels of the pre-test and post-test

\begin{tabular}{lll}
\hline Level Scores of Pre-test and Post-test & $\mathbf{N = 3 3}$ & $\mathbf{\%}$ \\
\hline Decrease & - & - \\
Be the same & - & - \\
Increase & 33 & 100.0 \\
Total & $\mathbf{3 3}$ & $\mathbf{1 0 0 . 0}$
\end{tabular}

According to the results of the study, table 3 found that the post-test score of 33 learners increased over the pre-test score of $100.0 \%$.

4.1.4 The Different Level Scores of Four Exercises

Table 4. Comparison of Level Scores of Four Exercises

\begin{tabular}{lllllll}
\hline \multirow{2}{*}{ Exercise } & \multicolumn{2}{l}{ Level Scores } & & & \\
\cline { 2 - 6 } & Excellent & Good & Fair & Poor & Very poor & Missing \\
\hline Exercise 1 & $3(9.1)$ & $30(90.9)$ & - & - & - & - \\
Exercise 2 & $4(12.1)$ & $29(87.9)$ & - & - & - & - \\
Exercise 3 & $13(39.4)$ & $19(57.6)$ & $1(3.0)$ & - & - & - \\
Exercise 4 & $3(9.1)$ & $28(84.8)$ & $1(3.0)$ & - & - & $1(3.0)$ \\
\hline
\end{tabular}

Table 4 showed the comparison of level scores of four essay writing exercises. A total score of 30 was calculated as follows:

1) The writer's ideas are supported by data and experiences. (10 points)

2) Essay structure (10 Points)

3) Central point and description of ideas (5 Points)

4) Design (5 Points)

Hence, the level scores of exercise 1 had the highest scores from 30 learners who were at a good level (90.9\%), followed by 3 learners who were at excellent levels $(9.1 \%)$. Next, the level scores of exercise 2 had the scores from 29 learners who were at a good level $(87.9 \%)$, followed by 4 learners who were at excellent levels $(12.1 \%)$. Then the level scores of exercise 3 had the scores from 19 learners who were at a good level (57.6\%), followed by 13 learners who were at excellent levels (39.4\%), and 1 learner which was at a fair level (3.0\%). Finally, the level scores of exercise 4 had the scores from 28 learners which were at a good level $(84.8 \%)$, followed by 3 learners who were at excellent levels $(9.1 \%), 1$ learner which was at fair level $(3.0 \%)$, and 1 learner which was at missing $(3.0 \%)$. In conclusion, the learners' ability of writing before and after receiving the e-Writing instructional design program was different. According to the achievement results, the scores from the pre and post-tests were significantly different. The scores from the post-test were higher than the scores from the pre-test. The learners could produce their exercises with higher scores. This meant that the teaching delivery method using the e-Writing instructional design program assisted learners to significantly improve their Essay writing ability. 
4.1.5 The Perception of Learners toward E-Writing Instructional Design Program

Table 5. Learners' satisfaction toward e-Writing instructional design program

\begin{tabular}{|c|c|c|c|}
\hline Learner Satisfaction & & SD. & Meaning \\
\hline 1. Learners are satisfied with e-Writing instructional design program & 4.27 & .574 & Excellent \\
\hline 2. The teaching methodology is suitable for learning English Writing & 4.45 & .617 & Excellent \\
\hline $\begin{array}{l}\text { 3. Learners often learn with e-Writing instructional design program and } \\
\text { practice being responsible }\end{array}$ & 4.24 & .502 & Excellent \\
\hline 4. Learners like to practice writing with e-Writing instructional design program & 4.24 & .502 & Excellent \\
\hline $\begin{array}{l}\text { 5. Learners gain more academic knowledge with e-Writing instructional design } \\
\text { program }\end{array}$ & 4.15 & .508 & Good \\
\hline 6. The teaching methods affect the learner's study & 4.27 & .574 & Excellent \\
\hline 7. Learners have no limit to study and can study any time and place & 4.70 & .529 & Excellent \\
\hline $\begin{array}{l}\text { 8. It is convenient for learners to review the lesson outside the classroom using } \\
\text { e-Writing instructional design program }\end{array}$ & 4.42 & .502 & Excellent \\
\hline 9. Using this teaching media allows learners to meet their learning objectives & 4.18 & .528 & Good \\
\hline $\begin{array}{l}\text { 10. Learners have the freedom to study from e-Writing instructional design } \\
\text { program }\end{array}$ & 4.48 & .619 & Excellent \\
\hline Total & 4.34 & .546 & Excellent \\
\hline
\end{tabular}

According to table 5, the satisfaction level of undergraduate learners towards the instruction of this course had average scores at 4.34 which was an excellent level.

4.1.6 Learner Autonomous Learning after Receiving E-Writing Instructional Design Program

Table 6. Learners' autonomous learning toward e-Writing instructional design program

\begin{tabular}{lccc}
\hline Learner's Autonomous Learning & & SD. & Meaning \\
\hline 1. The teaching methods create an autonomous learning atmosphere & 4.52 & .508 & Excellent \\
2. Learners are happy and have fun in their learning & 4.42 & .502 & Excellent \\
3. Learners enjoy learning with e-Writing instructional design program & 4.27 & .574 & Excellent \\
4. The teaching methods are suitable for learner-center e-writing & 4.39 & .496 & Excellent \\
5. The teaching methods motivate learners to improve writing skills & 4.39 & .496 & Excellent \\
Total & $\mathbf{4 . 4 0}$ & $\mathbf{. 5 1 5}$ & Excellent \\
\hline
\end{tabular}

According to table 6, the autonomous learning of undergraduate learners towards the instruction of this course had average scores at 4.40 which was an excellent level.

Table 7. Comparison between the level of satisfaction and autonomous learning of learners

\begin{tabular}{lllllll}
\hline \multirow{2}{*}{ Evaluation Lists } & \multicolumn{2}{l}{ Level of Satisfaction } & & & \\
\cline { 2 - 6 } & Excellent & Good & Fair & Poor & Very poor & Missing \\
\hline Learners' Satisfaction & $26(78.8)$ & $7(21.2)$ & - & - & - & - \\
Learners' Autonomous Learning & $22(66.7)$ & $11(33.3)$ & - & - & - & - \\
\hline
\end{tabular}

According to table 7, the level learners' satisfaction toward of this course found that 26 learners were satisfied at excellent level (78.8\%), followed by 7 learners at a good level (21.2\%). The learners' autonomous learning toward of this course, 22 learners were satisfied at excellent level (66.7\%) followed by 11 learners at a good level (33.3\%) respectively. 


\subsection{Qualitative Data Report}

In the next section of this study the qualitative data will be discussed in two parts. Learners' satisfaction will be analyzed first followed by the learner's autonomous learning. In the category of satisfaction, participants expressed their opinion positively, and satisfaction toward the e-Writing instructional design program. Participants expressed different satisfaction in terms of the benefit of this program, the appropriate program for learning, and the learning atmosphere. During their instruction, they felt relaxed because there was no time limitation to study. The technology used enabled the learners to study at school and outside school. Next, the category of the learning experience, the participants mentioned that they could improve their essay writing skills and realized writing processes. The convenience of the technology used in the lessons and the cordon were emphasized.

Moreover, the learners had responsibility for their study. Lastly, the category of recommendation, the participants' opinion, they would like all subjects to design the learning material and course using technological tools. According to this program, they could learn as much as they wanted, and they could practice their lessons without time limitation. From the learners' point of view, this program was quite challenging and motivating for all learners to learn rather than learning in a regular classroom. Some of the participants felt that a blended learning method should be used over a traditional learning method. This meant that some learners would like to study with traditional teaching methods sometimes, and they would like to study online learning sometimes.

For the results from the interview question toward learner's autonomous learning, the results from the interview questions presented a different point of view. First, in the category of the learning experience, the learners had a positive point of view toward the e-Writing instructional design program. They mentioned that studying with e-Writing created an autonomous learning atmosphere, had fun in their learning, and reinforced a learner-centered approach. The participants also felt that their motivation, responsibility, and promptness were reinforced. Autonomous learning was also reinforced because the participants were enabled to practice by themselves on their own time. For the category of satisfaction, the learners mentioned positively. They claimed that they could study at any time and place without limitation. It was convenient for them to review the lesson outside the classroom using an e-Writing instructional design program. The e-Writing program was enjoyable and relaxing to study in. They were satisfied with it in terms of a relaxed learning environment. Additionally, their writing skill was improved, and they had more responsibility in their study.

\section{Discussion}

According to research question 1, there are differences in learners' e-Writing instructional design programs before and after their study. The delivery teaching method of the e- Writing instructional design program was effective for learners to study. The writing achievement level of the learners before and after receiving the treatment was significantly different at 0.001 . The post-test score of 33 learners increased over the pre-test score of $100.0 \%$.

The result was congruent with the study of Peregoy \& Boyle (2012) who insisted that technology is a powerful tool to motivate learners and allowed them to reflect on their learning achievements. Also, Richardson (2010) insisted that integrating technology such as World Wide Web, Blog, or Wiki in classroom instruction would be the useful tool's potential for collaborative learning among learners, and instructors. Likewise, to encourage the learners' learning atmosphere, Alanazi (2013) explained that incorporating electronic writing into a lesson can have a positive effect on the learner's motivation. Casual electronic writing can also increase the learner's pleasure in a learning course as well as build the learner's self-confidence to overcome formal writing assignments. Geluso (2013) asserted that the learners were able to improve their writing skills via Google sites, also. To support this study's outcomes (Razali \& Khatimah, 2013; Smith \& Craig, 2013; Merzifonluoglu \& Gonulal, 2018), these authors pointed out that when learners work together, through technology, they will feel more ownership of their tasks. This can encourage learners to become more independent learners. With that in mind, educators should find relevant ways to incorporate technology into their lessons to promote learner autonomy and efficient learning outcomes.

According to research question 2, the learners were satisfied with the e-Writing instructional design program. The satisfaction level of undergraduate learners towards the instruction of this course had average scores of 4.34 which was an excellent level. A study by Zarei \& Gahremani (2010) and Liu, Liu \& Tu (2020) claimed that autonomous learners are typically more motivated to participate in a language lesson and will work harder during their study time. In the same way, Gditawi, Noah, \& Abdul Ghani (2011) showed that learners' motivation affected their learning. Because the learners could study anytime and anywhere, they were encouraged to become more independent. This was congruent with the results of previous studies (Emily, 2011; Vurdien, 2013). Technological education, like e-Writing instructional design programs, provides fun new learning experiences for the learners. Multiple researchers agree that e-Writing has many advantages when integrated into language lessons (Khamkhien, 
2012; Reeve, 2013; Cutter, 2015; Merzifonluoglu \& Gonulal, 2018; Shadiev \& Yang, 2020). E-Writing is simple to use, easy to access and allows the learners to organize their writing. Websites like Google can improve the learners writing ability by giving them access to text with natural language patterns.

According to research question 3 , the e-Writing instructional design program promoted autonomous learning. The results from the coding interview will be discussed in each category. At first, the category of satisfaction, the learners were satisfied with the e-Writing instructional design program because e-Writing could improve learners' writing skills and other skills such as vocabulary. A study by Geluso (2013) mentioned that e-Writing can promote proper writing through access to text with natural language patterns. In addition, the interview's results showed that they were motivated which was related to their autonomous learning. A study conducted by Gupta and Woldemariam (2011) showed that learners with high motivation enjoyed and took pride in their writing assignments. Second, the category of learning experience after the learners studied with the e-Writing instructional design program, the participants expressed a positive attitude toward their teaching delivery method. In this study, learner autonomy is described as the learner's ability to facilitate their learning. Learners' autonomy and higher achievement, in language learning, complement each other. Autonomous learning is an indicator of higher achievement (Vurdien, 2013). E-Writing instructional design program helped them to become autonomous learners. Merzifonluoglu \& Gonulal (2018) confirm that independent learners are more diligent in their studies. Finally, in the category of recommendations, the participants gave comments and recommended the need for further development in terms of adding more essay samples of each essay type, a sample of youtube links which related to each essay type, and essay tips to become good essay writing. A study by Richardson (2010) suggested that integrating technology such as World Wide Web, Blog, or Wiki in the classroom instruction would be the useful tool's potential for collaborative learning among learners, and instructors can use these tools to reinforce language through authentic audio and visual media. Technology could be used to reinforce and practice the learner's pronunciation, grammar knowledge, and lexicon.

\section{Recommendations of the Study}

Technological devices have positive effects on language learning. The researcher expected the recommendations for future practice might assist instructors to use and design the chapters effectively. Research into the long-term achievement of learners, using technology, needs to be conducted. Also, the researcher expected that the category of research recommendations might encourage other researchers to continue to study this field to design more effective learning media. Instructors need to know how to apply technology in the classroom, and learners need to be exposed to learning techniques in the language classroom.

To be successful in EFL learning, pedagogical approaches with technology should be employed. To ensure high achievement in language learning, educators need to find suitable language teaching methods for their learners.

\section{Limitations of the Study}

One limitation of this study was the difficulty to control the learner's participation. Also, differences in the learners' computer skills affected their study. In addition, the researcher could not control the learners who studied their lessons after they finished classes using this program outside the classroom. Finally, the researcher could not control learners who did not wish to participate in the e-Writing instructional design program during their learning process. A typical random sampling method could not be used in this study because of the low number of learners enrolled in the e-Writing program. The learners were assigned to particular sections. This meant that the learners could not be switched between different sections.

\section{Conclusions}

The rapid development of technology gives educators and learners new exciting ways to partake in language learning. The results presented show that technology can support and enhance language learning when applied correctly by the educator. The target language can be more accessible for learners with technology. Convenient ways to input text and fast feedback from peers and instructors make learning with technology advantageous. Instructors can employ more engaging and relevant language lessons with technological resources. Interacting with multiple learners is one of the most challenging aspects of language teaching, and Technology can provide a more efficient means to accomplish this. In terms of pedagogical resources and connecting with younger generations modern technological education, like e-Writing instructional design programs in this study, can provide learners more engaging materials and promote higher language achievement. The results of this study show that technology should not replace traditional teaching methods but reinforce them. Proper use of technology in a language lesson can help learners meet literacy goals and enhance the language classroom. 


\section{References}

AbuSeileek, A., \& Abualsha'r, A. (2014). Using peer computing-mediated corrective feedback to support EFL learners' writing. Language Learning \& Technology, 18(1), 76-95. Retrieved from https://lt.msuedu/issues/february2014/abyseileekabualshar.pdf

Ahmadi, M. R. (2017). The impact of motivation on reading comprehension. International Journal of Research in English Education, 2(1). https://doi.org/10.18869/acadpub.ijree.2.1.1

Alanazi, M. A. (2013). Using electronic writing to promote learners' writing. EWU Masters Thesis Collection. 116. Retrieved from https://dc.ewu.edu/theses/116

Albalawi, R. B. (2015). The effect of different teaching delivery method (Face to face, virtual and blended on intermediate learners' academic achievement. West East Journal of Social Sciences, 1(4), 29-45. Retrieved from https://www.westeastinstitute.com

Albesher, K. B. (2012). Developing the writing skills of ESL learners through the collaborative learning strategy. Thesis submitted for the degree of Doctor of Philosophy (Integrated) in Education and Applied Linguistics. School of Education, Communication and Language Sciences Newcastle University.

Al-haisoni, M. (2012). An Analysis of Article Errors among Saudi Female EFL Learners: A Case Study. Asian Social Science Canadian Center of Science and Education, 8(12), 55-66. https://doi.org/10.5539/ass.v8n12p55

Allen, M. (2017). Designing Online Asynchronous Information Literacy Instruction Using the ADDIE Model. In T. Maddison \& M. Kumaran (Eds.), Distributed Learning (pp. 69-91). Chandos Publishing: Elsevier. https://doi.org/10.1016/B978-0-08-100598-9.00004-0

Basheer, B. (2013). The impact of Using Technology in teaching English as a Second Language. English Language and Literature Studies, 3(1), 111-116. https://doi.org/10.5539/ells.v3n1p111

Bouchrika, I. (2020). A guide to the different types of writing. Retrieved from https://www.guide2research.com

Branch, R. M. (2018). Characteristics of instructional design models. In R. A. Reiser \& J. V. Dempsey (Eds.), Trends and issues in instructional design and technology (4th ed., p. 28). New York: Pearson Merrill Prentice Hall.

Cavender, A. (2012). All things Google: Using Google for writing portfolios. The Chronicle of Higher Education: Prof Hacker. Retrieved from https://chronicle.com/blogs/profhacker/all-things-google-using-google-for-writingportfolios/38324

Chappell, S. (2011). Utilizing the aesthetics of destabilization to read the public pedagogy in young people's community-based social justice artworks. Journal of Curriculum Theorizing, 27(3). Retrieved from https://journal.jctonline.org

Cobanoglu, C., \& Berezina, K. (2011). The impact of the use of blogs on learners' assignment engagement. Journal of Hospitality, Leisure, Sports and Tourism Education, 10(1), 99-105.

Cutter, M. (2015). Using Technology with English Language Learners in the Classroom. Education Masters. Paper 313.

Dafei, D. (2007). An Exploration of the Relationship between Learner Autonomy \& English Proficiency. Asian ELT Journal, 24, 1-24. Retrieved from https://asian-efl-journal.com/

David, L., Keaton, R., Morris, R., Murphy, J. G., \& Stapley, I. (2008). A Space for writing: developmental writing instruction in a technology-enhanced classroom. Creation of the Space: Form Follows Function.

Davis, A. L. (2013). Using instructional design principles to develop effective information literacy instruction: The ADDIE model. College \& Research Libraries News, 74(4), 205-207. https://doi.org/10.5860/crln.74.4.8934

Emily, R. L. (2011). Motivation: A Literature Review. The effect of motivation on English writing skills among Jordanian 10th-grade learners in Al-Karak Directorate of Education during the second.

Fox, Leah C. C. (2014). Effects of technology on literacy skills and motivation to read and write. Education and Human Development Master's $\quad$ Theses. $522 . \quad$ Retrieved from https://digitalcommons.brockport.edu/ehd_theses/522

Gditawi, F., Noah, M., \& Abdul Ghani, Q. (2011). The relationship between motivation and learning reading and writing in sixth graders in the Hashemite Kingdom of Jordan. Journal of Islamic and Arabic Education, 3(1), $13-28$. 
Geluso, J. (2013). Phraseology and frequency of occurrence on the web: Native speakers' perceptions of Google-informed second language writing. Computer Assisted Language Learning, 26(2), 144-157. https://doi.org/10.1080/09588221.2011.639786

Gençlter, B. (2015). How does technology affect language learning process at an early age? Procedia - Social and Behavioral Sciences, 199(3), 311-316. https://doi.org/10.1016/j.sbspro.2015.07.552

Graham, S., Gillespie, A., \& McKeown, D. (2013). Writing: Importance, development, and instruction. Reading and Writing, 26, 1-15. https://doi.org/10.1007/s11145-012-9395-2

Gregoriades, A., Pampaka, M., \& Michail, H. (2009). Assessing learners' learning in misusing concept mapping. Journal of Information Systems Education, 20(4), 419-430. Retrieved from https://jise.org/default.html

Gupta, D., \& Woldemariam, G. S. (2011). The influence of motivation and attitude on writing strategy use of undergraduate EFL learners: quantitative and qualitative perspectives. The Asian EFL Journal Quarterly, 13(2). Retrieved from https://www.asian-efl-journal.com

Haris, M., Yunus, M., \& Badusah, J. (2017). The Effectiveness of Using Padlet in ESL Classroom. International Journal of Advanced Research (IJAR), 5(2), 783-788. https://doi.org/10.21474/IJAR01/3214

Harmer, J. (2011). An introduction to the practice of English language teaching (4th ed.). United Kingdom: Pearson, Longman.

Kathryn Sorg, R. (2014). Identifying Errors in ESL Writing. A Thesis Submitted to the Graduate Faculty as partial fulfillment of the requirements for the Master of Arts Degree in English. The University of Toledo.

Khamkhien, A. (2012). Computer assisted language learning and English language teaching in thailand: Overview. Mediterranean Journal of Social Sciences, 3(1), 55-64.

Kranthi, K. (2017). Technology Enhanced Language Learning (TELL). International Journal of Business and Management Invention, 6(2), 30-33. Retrieved from https://www.ijbmi.org

Lin, Meng-ying. (2015). Collaborative Writing in a Computer-Supported Classroom: Mediation, and Self-Assessed Beliefs and Attitudes about Writing. Unpublished doctoral dissertation. University of Toronto.

Little, D. (2007). Language learner autonomy: Some fundamental considerations revisited. ELT Journal, 1, 14-29. https://doi.org/10.2167/illt040.0

Liu, X., Liu, Y., \& Tu, F. J. (2020). Multimedia technology and learner autonomy: an experimental study for asymmetric effects. Symmetry, 12(3), 462. https://doi.org/10.3390/sym12030462

Malloy, J. A., \& Gambrell, L. B. (2006). Approaching the unavoidable: Literacy instruction and the Internet. International Reading Association, 59(5), 482-484. https://doi.org/10.1598/RT.59.5.8

Maniam, M. (2010). The influence of first language grammar (L1) on the English language (L2) writing of Tamil School learners: A case study from Malaysia. Language in India, 10, 1-209. Retrieved from https://www.languageinindia.com

Marek, M. (2014). The integration of technology and language instruction to enhance EFL learning. Department of Communication Arts: Wayne State College.

Merzifonluoglu, A., \& Gonulal, A. (2018). Review of Digital language learning and teaching: Research, theory, and practice. Language Learning \& Technology, 22(1), 65-68. Retrieved from https://scholarspace.manoa.hawaii.edu/

Mollaei, F. (2013). Instructors' perceptions of using technology in teaching EFL. International Journal of Applied Linguistics \& English Literature, 2(1), 13-22. https://doi.org/10.7575/ijalel.v.2n.1p.13

Omar, A., \& Miah, M. (2012). Impact of technology on teens' written language. International Journal of Advanced Trends in Computer Science and Engineering, 1(1). Retrieved from https://www.warse.ijatcse.current

Oxkert, D. (2018). Using a Tablet Computer for EFL Positive Self-Review: increases in Self-Determination Theory-Based Learning Motives. Calido Journal, 35(2), 1-18. https://doi.org/10.1558/cj.32185

Parvin, R. H., \& Salam, S. F. (2015). The effectiveness of using technology in English language classrooms in government primary schools in Bangladesh. FIRE: Forum for International Research in Education, 2(1), 47-59. https://doi.org/10.18275/fire201502011049 
Peregoy, S., \& Boyle, O. (2012). Reading, writing and learning in ESL: A resource book for instructors. New York: Allyn \& Bacon.

Peterson-Karlan, G., Hourcade, J., \& Parette, P. (2008). A Review of assistive technology and writing skills for learners with physical and educational disabilities. Physical Disabilities: Education and Related Services, 26(2), 13-32. Retrieved from https://ir.library.illinoisstate.edu/

Potter, D. (2019). Writing tips: 4 essential types of writing styles. Retrieved from https://www.grammarly.com

Pourhosein, A., Banou, N., \& Zabihniaemran, A. (2015). What are the barriers in the use of computer technology in EFL instruction? Review of European Studies, 7(11), 213-221. https://doi.org/10.5539/res.v7n11p213

Pourhossein Gilakjani, A. (2017). A review of the literature on the integration of technology into the learning and teaching of English language skills. International Journal of English Linguistics, 7(5), 95-106. https://doi.org/10.5539/ijel.v7n5p95

Prakash, P. (2007). Psychological Foundation of Education. New Delhi: Kanishka Publishers.

Purcell, K., Buchanan, J., \& Friedrich, L. (2013). The impact of digital tools on learner writing and how writing is taught in schools. National Writing Project. Pew Research Center. Retrieved from https://www.pewinternet.org/2013/07/16/the-impact-of-digital-tools-on-learner-writing-and-how-writing-istaught-in-schools/

Razali, K., \& Khatimah, H. (2013). Autonomous learning writing promoted by the use of facebook. Research Gate, 6(2), 1-23. https://doi.org/10.18326/rgt.v6i2.239

Reeve, J. (2013). How learners create motivationally supportive learning environments for themselves: The concept of agentic engagement. Journal of Educational Psychology, 105(3), 579-595. https://doi.org/10.1037/a0032690

Richardson, W. (2010). Blogs, wikis, podcasts, and other powerful web tools for classrooms. SAGE Publications.

Ridha, N. (2012). The Effect of EFL Learners' Mother Tongue on their Writings in English: An Error Analysis Study. Journal of the College of Arts. University of Basrah, 60, 22-45. Retrieved from https://www.researchgate.net

Rojas, G. (2011). Writing using blogs: A way to engage Colombian adolescents in meaningful communication. Profile, 13(2), 11-27. Retrieved from https://www.scielo.org.co/

Salima, R. (2012). Measures of eliminating efl learners' errors in writing. Procedia - Social and Behavioral Sciences, 69, 318-327. https://doi.org/10.1016/j.sbspro.2012.11.416

Sarfraz, S. (2011). Error analysis of the written English essays of Pakistani undergraduate learners: A case study. Asian Transactions on Basic and Applied Sciences, 1(3), 29-50. Retrieved from https://www.academia.edu

Sawalmeh, M. (2013). Error analysis of written english essays: the case of learners of the preparatory year program in saudi arabia. English for Specific Purposes World, 40(14), 1-17. Retrieved from https://www.esp-world.info

Scott, P., \& Mouza, C. (2007). The impact of professional development on instructor learning, practice, and leadership skills: A study on the integration of technology in the teaching of writing. J. Educational Computing Research, 37(3), 229-266. https://doi.org/10.2190/EC.37.3.b

Shadiev, R., \& Yang, M. (2020). Review of studies on technology-enhanced language learning and teaching. Sustainability, 12, 524. https://doi.org/10.3390/su12020524

Smith, K., \& Craig, H. (2013). Enhancing the autonomous use of CALL: A new curriculum model in EFL. CALICO J., 30, 252-278. https://doi.org/10.11139/cj.30.2.252-278

Stanley, G. (2013). Language Learning with Technology: ideas for integrating technology in the classroom. Cambridge: Cambridge University Press.

Stine, L. J. (2010). Teaching basic writing in a web-enhanced environment. Journal of Basic Writing, 29(1), 33-55. https://doi.org/10.37514/JBW-J.2010.29.1.03

Vurdien, R. (2013). Enhancing writing skills through blogging in an advanced English as a foreign language class in Spain. Computer Assisted Language Learning, 26(2), 126-143. https://doi.org/10.1080/09588221.2011.639784 
Walsh, K. (2010). The importance of writing skills: Online tools to encourage success. Retrieved from https://www.emergingedtech. com/2010/11

Zarei, A. A., \& Gahremani, K. (2010). On the relationship between learner autonomy and reading comprehension. Retrieved from https://www.ikiu.ac.ir/public-files/profiles/items/090ad_1424769045.pdf

Zawahreh, F. (2012). Applied Error Analysis of Written Production of English Essays of Tenth Grade Learners in Ajloun Schools, Jordan. International Journal of Learning and Development, 2(2), 16-35. https://doi.org/10.5296/ijld.v2i2.1680 


\section{Appendix}

Writing Test (Pretest and Posttest) 30 Points

Directions: In this part of the test, you will write an essay in response to a question that asks you to state, explain, and support your opinion on an issue. Typically, an effective essay will contain a minimum of 500 words.

Your response will be scored on:

1) Your opinion is supported with reasons and/or examples (10 Points)

2) Organization (10 Points)

3) Focus and Details (5 Points)

4) Mechanics (5 Points)

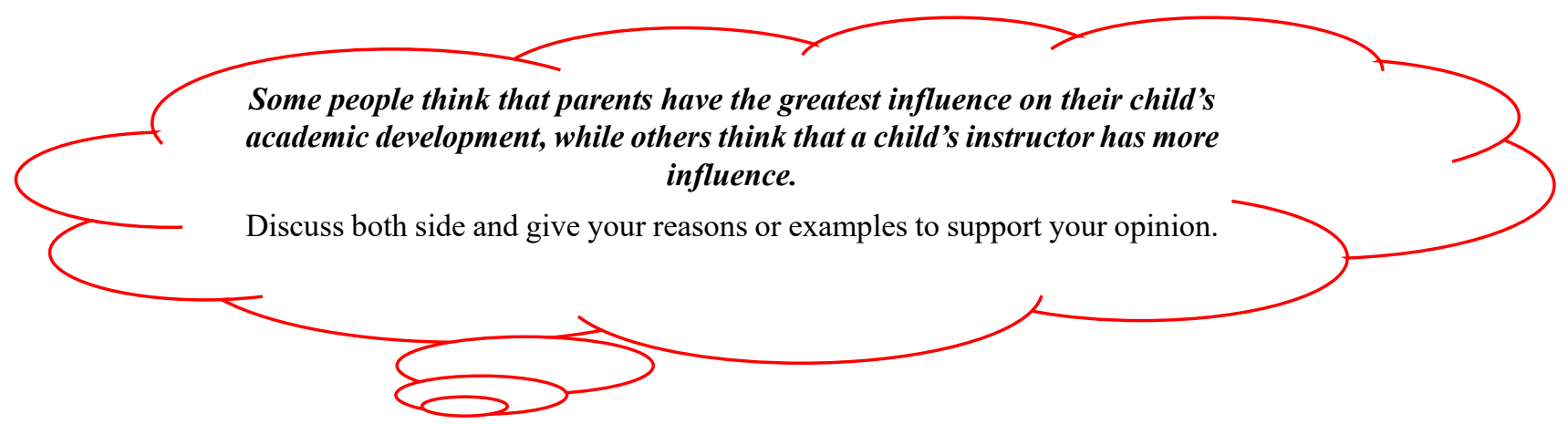

Resources: Adapted from https://ieltsliz.com/100-ielts-essay-questions

\section{Sample of Homepage of Essay course}

\section{E S S A Y}

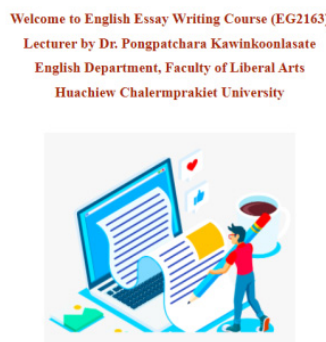




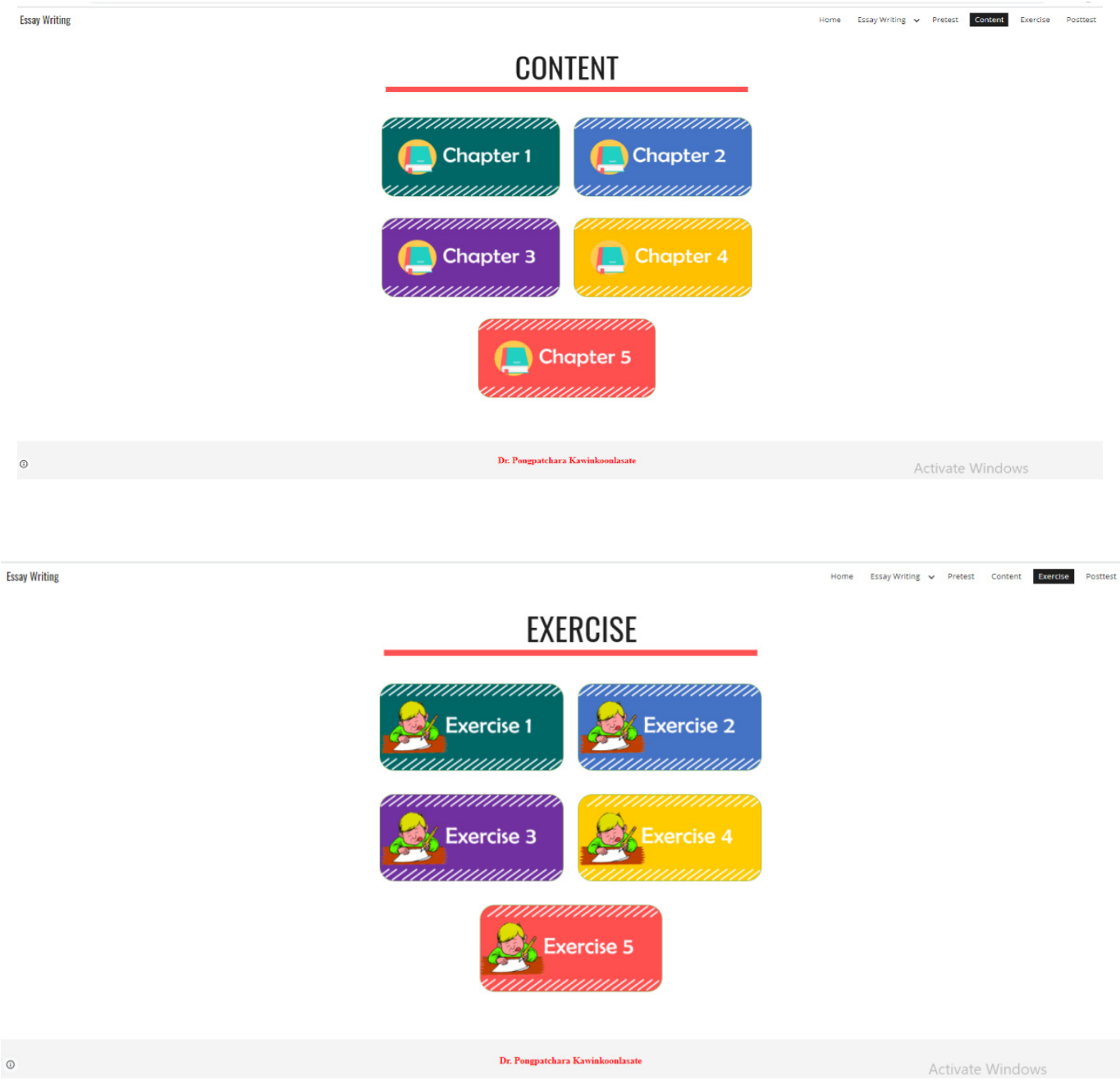

\section{Argumentative Essay}

Directions: Write an argumentative essay by your own topic. Use four stops in the writing
process.

*จำเปิน

Name *

คำตลบรลงงตุด

Student ID

ค่าตลบรมงคุด

Step 1: Pre-writingchoose the topic given that you are interested in and you have experience with. Students should think about the issue and pick the side effective argumentative essay the writer must understade the wirea an perspective. Is the reader undecided or inclined to favor one side or the

other? For an argumentative essey, your topic can be developed at least three solid points with the two subjects. You are able to choose one from the suggestion topics in Appendix A (Topic Suggestions: ArgumentativeEssay). As What do the readers know?" "You will write a thesis statement which expreses your point of view about that issue. The thesis statement should be a statement not a question. Write down your arguments and counterargument of each issue. 


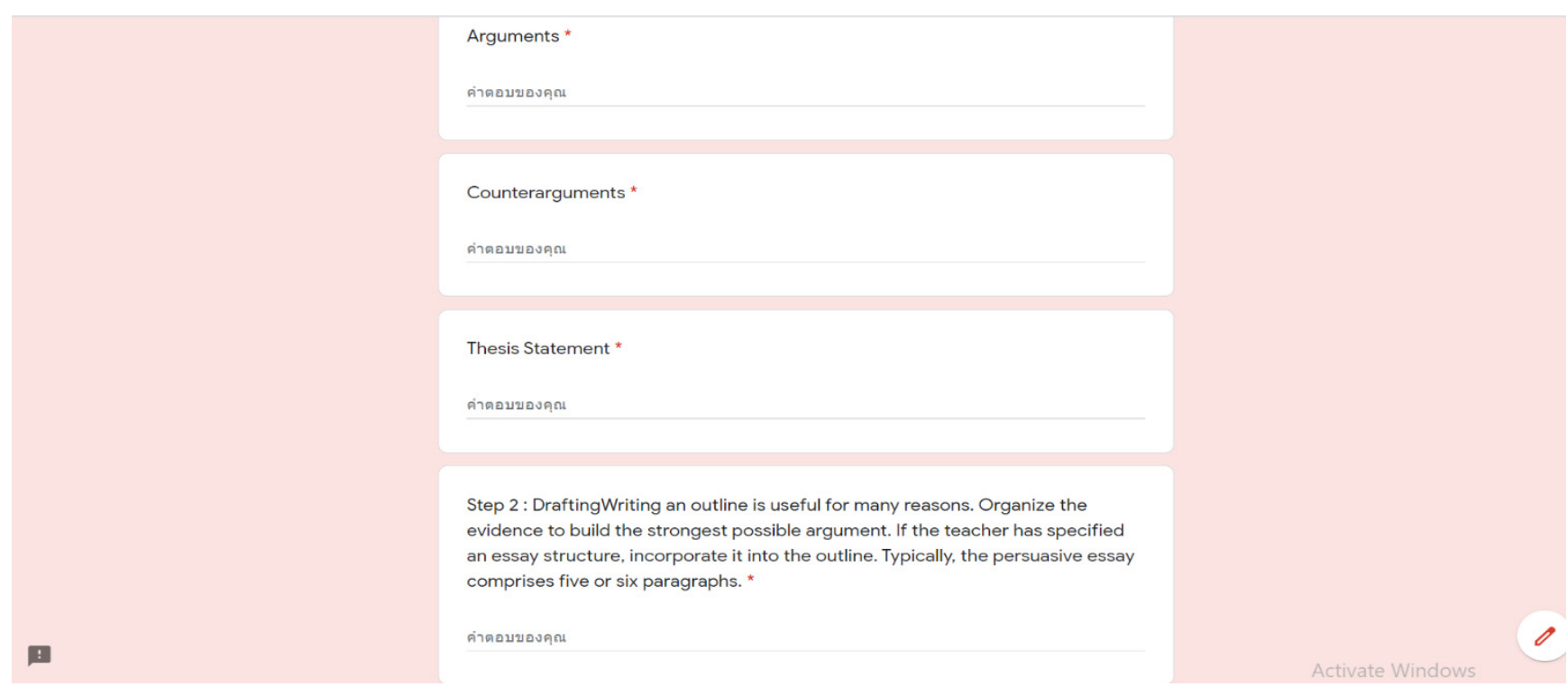

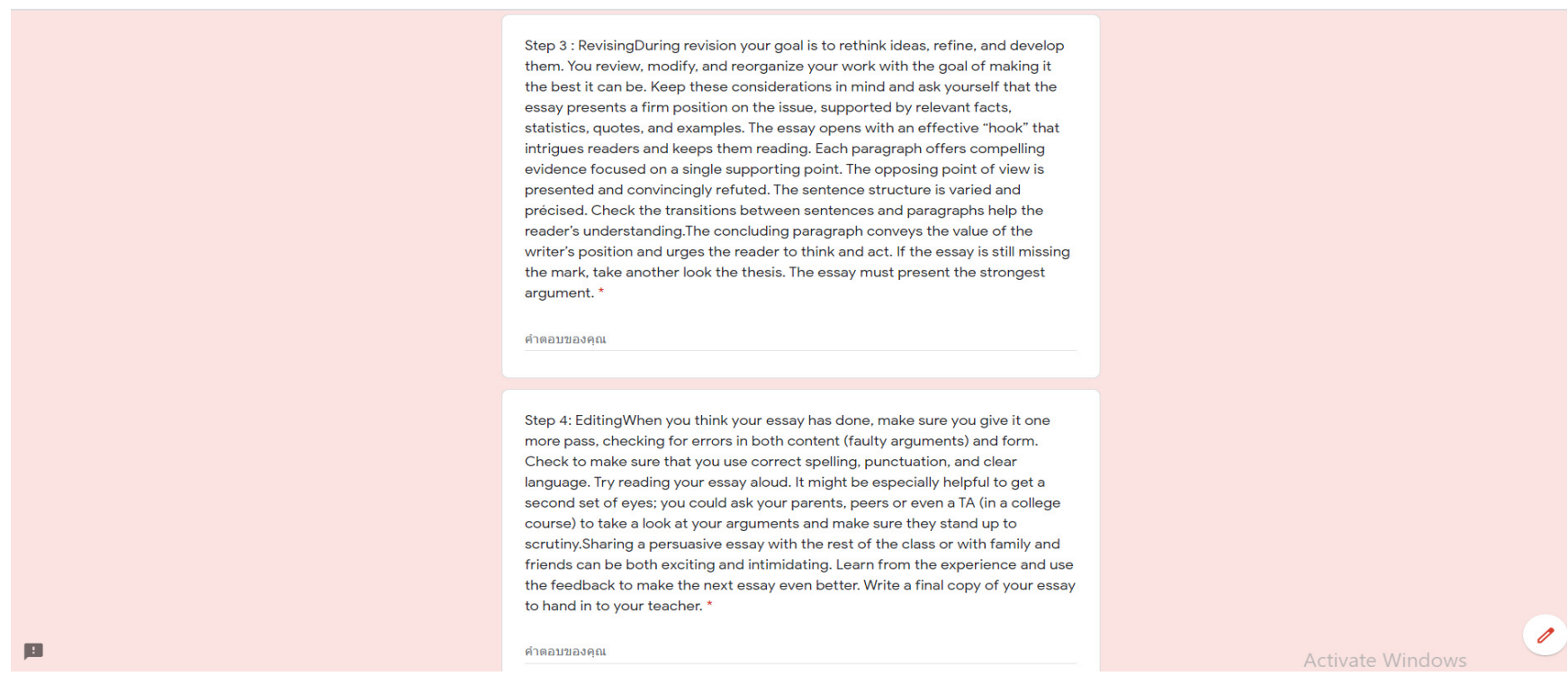

\section{Copyrights}

Copyright for this article is retained by the author(s), with first publication rights granted to the journal.

This is an open-access article distributed under the terms and conditions of the Creative Commons Attribution license (http://creativecommons.org/licenses/by/4.0/). 